\title{
CHARACTERIZATION AND PATHOGENIC POTENTIALS OF ZNO NANOPARTICLES FROM ORGANIC EXTRACT OF BARRINGTONIA ASIATICA STEM BARK
}

\author{
Isaac John Umaru \\ Federal University Wukari, Faculty of Pure and Applied Science, Department of Biochemistry. Taraba State Nigeria
}

Email: umaruisaac@gmail.com

\begin{abstract}
Barringtonia asiatica (L.) Kurtz belong to a Family of Lecythidaceae, is a species native to mangrove habitats in the tropical with a pinkish grey stem bark. It has been commonly used in traditional medicine for a range of ailments and is consumed as raw vegetable in Malaysia. The aim of the study was to synthesis and to evaluate the antibacterial activity of ZnO nanoparticles (NPs) from organic extracts of Barringtonia asiatica stem-bark using zinc chloride $(\mathrm{ZnCl} 2)$ and zinc acetate dehydrate [ $\mathrm{Zn}$ $\left.\left(\mathrm{CH}_{3} \mathrm{COO}\right)_{2} \cdot 2 \mathrm{H}_{2} \mathrm{O}\right]$ as precursors on selected Gram positive and Gram negative bacterial: Escherichia coli (Gram-ve), Staphylococcus aureus, (Gram +ve), Pseudomonas aeruinosa (Gram -ve), Bcillus anthracis (Gram+ve) and Klebsielia Pneumonia (Gram +ve). Obtained was a Spherical and flake-like nanostructures recorded by Scanning Electron Microscopy (SEM) for B.asiatica for the two precursors used. The average particle size and crystallite size determined by Transmission Electron Microscopy (TEM) and X-ray Diffraction (XRD) for B: asiatica were in the range of 31.868.0.26 $\mathrm{nm}$ and 31.6-67.7 $\mathrm{nm}$ respectively. To observe the purity and surface functional groups of the samples, Energy-dispersive X-ray spectroscopy (EDX), UV- visible spectroscopy (UV-vis), Atomic Absorption Spectroscopy (AAS) and Fourier-transform infrared spectroscopy (FT-IR) techniques were used and the Spectra peaks at 440-458 $\mathrm{cm}^{-1}$ and $364-370 \mathrm{~nm}$ confirmed the presence of $\mathrm{ZnO}$ in the samples by FT-IR and UV-vis, whereas AAS at $214.8 \mathrm{~nm}$ wavelength further confirmed elemental zinc with a percentage atomic weight of $72.16 \%$ as against $65.78 \%, 16.38 \%, 11.86 \%$ and $70.49 \%$, $15.32 \%, 12.26 \%$ for Zinc, Oxygen and Carbon by EDX. The result from the antibacterial activity studies show an increase in inhibition rate as concentration of the ZnO NPs increases in concentration from $25-1000 \mu \mathrm{g} / \mathrm{ml}$. ZnO NPs from B. asiatica stem-bark extracts recorded the highest inhibition rate in Staphylococcus aureus recorded the highest inhibition of $3.99 \pm 0.17 \mathrm{~mm}$ at $1000 \mu \mathrm{g} / \mathrm{ml}$ of Barringtonia asiatica stem-bark of ZnO precursor.
\end{abstract}

Key words: Characterization, pathogenic, $\mathrm{ZnO}$, Nanoparticles, Organic Extract, Barringtonia asiatica 

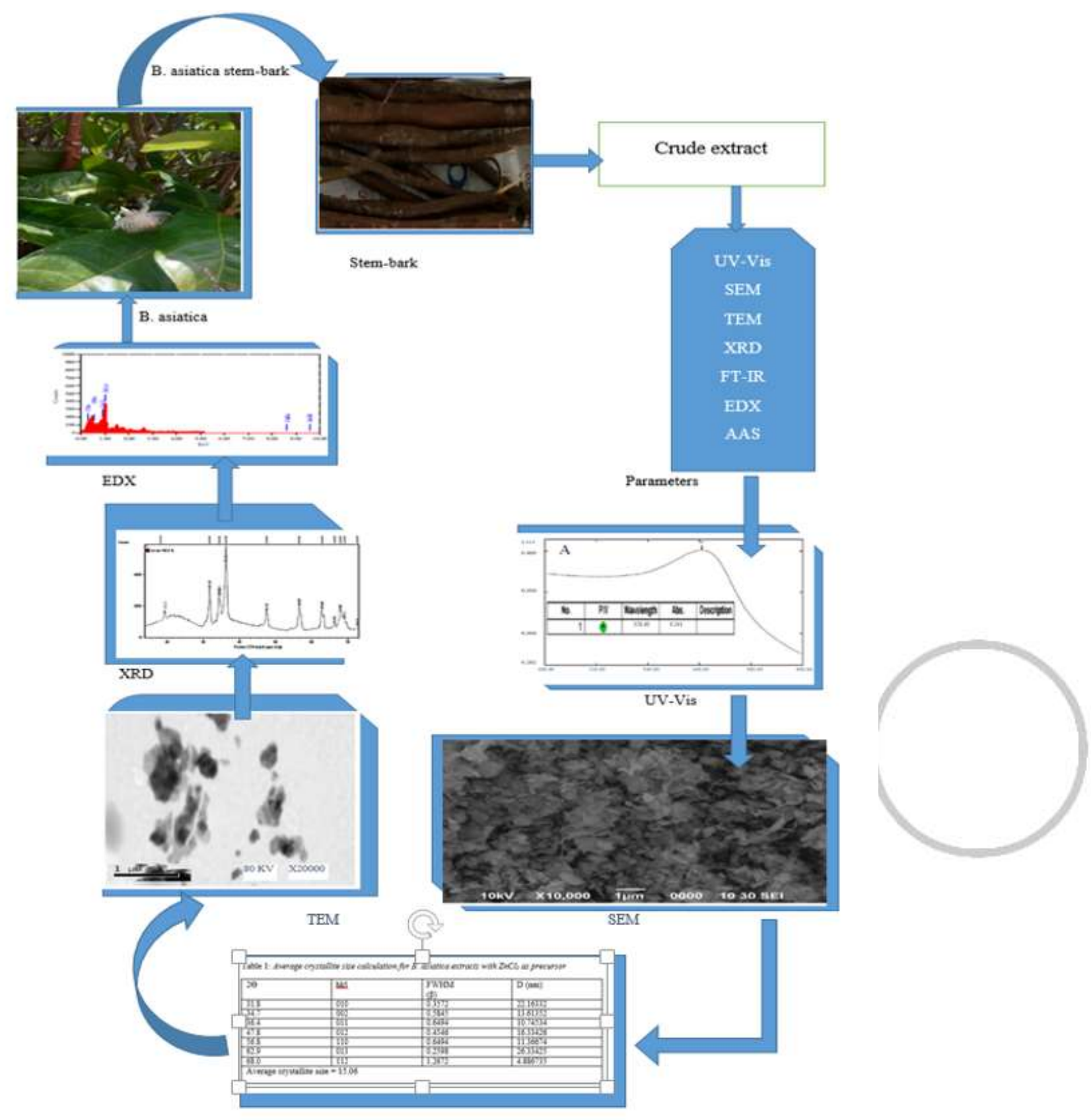

Average crystallite size

Figure 1: Structural abstract Synthesis, Characterization and pathogenic potentials of Nanoparticles of Barringtonia asiatica stem bark

\section{Introduction}

Natural Product are chemical substance produced by plants or animals; a term used commonly for chemical substances found in nature that have distinctive pharmacological effects. The main effects. The main such as body pain, ext
2021 May Edition / www.jbino.com | Innovative Association classes of natural products include; carbohydrates, lipids, proteins, nucleic acids and many more. They are usually used for traditional therapies for the treatment of various health problems such as body pain, exterior-relieving, 
digestive problem, blood regulating, physiological disorder swelling, and rheumatism based on herbal formulations. This discovery provides useful products, in spite of this successes, the pharmaceutical industry essentially abandoned natural product discovery about some decades ago (Baltz et al., 2017).

Most part of the world today continues to heavily rely on herbal remedies for their primary health care. Kampo medicine in Japan is not left out. Africa and Asian countries which are endowed with many traditional medicinal plants that can be used for pharmaceutical agents can be explored to remedies the health care challenge of modern medicine. Out of approximately 6400 plant species used in tropical Africa and Asia, more than 4000 are used as medicinal plants. Native Americans also have a long history of use of traditional medicines (Raymond \& George, 2015).

Barringtonia asiatica (L.) Kurtz belong to a Family of Lecythidaceae is a species native to mangrove habitats in the tropical. It is a common plant in the Malaysian Mangroves, and easily available in Kuching Wetlands Sarawak and Bako National Park. It is also found in tropical Africa especially in Nigeria and Madagascar. Its large pinkish-white, pompon flowers give off a sickly-sweet smell to attract bats and moths which pollinate the flowers at night. It is grown along streets for decorative and shade purposes in some parts of Sarawakian houses and it's also known as sea poison tree (Alfrits \& Suriani, 2016) or box fruit due to the distinct box-shaped of the fruit. It is a medium-sized tree growing to $7-25 \mathrm{~m}$ tall.

It is commonly known as the fish killer plant has been identified as a source of natural products. Study on some of the Barringtonia species from all parts of the world, Africa, Asia, India, China and Northern America have been widely conducted that led to the identification of some phytochemical such as amides, alkaloids, lignans, flavones, flavones, terpenes and steroids (Tanor et al., 2014). The stem-bark is pinkish grey and inhabitants of several West African countries Nigeria and the Polynesian Islands use liquid from the crushed bark of Barringtonia asiatica to treat chest pains and heart problems (Umaru et al., 2018). The same plant is used in Papua New Guinea to treat stomach-aches, where the leaves are squeezed into water and the liquid taken orally. It is also used for anti-rheumatic medication (Tanor et al., 2014)

However in recent years, microbial infection has become the cause of morbidity and mortality (Jones et al., 2008; Khan et al., 2016; Kumar et al., 2017) and as a result, their causative agents (virus, bacteria, pathogenic fungi, protozoa) have developed resistant strains that withstand their clinical treatment using concomitant anti-drugs (Yah \& Simate. 2015). When the highly potent antibiotics are used, they generate various side effects, thus they are reserved only for critical infectious diseases. Currently, new methods for combating antibacterial drug resistance are being researched (Imbela et al., 2017) resulting in the biosynthesis of nanoparticle with their diverse properties like chemical stability, catalytic activity, electrical conductivity, anti-inflammatory activities and antimicrobial (Nowack \& Bucheli. 2007; Bhattacharya \&Mukherjee.2008; Sharma et al., 2009). These properties are regulated by critical characteristics exhibited by nanoparticles 
and they include their size, shape distribution, lower toxicity and high surface-to-volume ratio (Sha et al., 2015; Stankic et al., 2016). Nano-particles have different applications in catalysts, sensors, electronic components, diagnostic imaging, pharmaceutical products, drug delivery, cancer therapy, cosmetic industry and biosensors (Bhattacharya \&Mukherjee. 2008; Nel et al., 2006; Singh et al., 2014).

Zinc oxide nanoparticles (ZnO NPs) can be synthesized through different techniques including microwave-assisted synthesis, sol gel, spray pyrolysis, chemical vapour deposition, co-precipitation, thermal decomposition, hydrothermal and combustion methods, wet chemical route, vapour phase process, precipitation and sonochemical method (Peralta-Videa et al., 2016; Hu et al., 2010; Wang, et al., 2014; Chen et al., 2015; Tien et al., 2013; Khorsand, et al., 2013; Omri, et al., 2014; Khorsand, et al., 2011; Wang et al., 2010). These chemical methods of synthesis are not environmentally friendly due to their chemical toxicity to the environment and high energy demand. Because of these draw backs, green synthesis or biosynthesis using environmentally friendly microorganisms (plant genus, biodegradable polymers (chitosan), bacteria and fungi) has been accepted as a promising technique to remedy the constraints accompanied with the above-mentioned methods (Sundrarajan et al., 2015; Olad et al., 2018). Biosynthesis often involves the use of plant extracts in single steps, clean, safe and cost effective approach [24]. Of late, plant extracts are employed and utilized due to their availability, biocompatibility, stability, as well as their ability to serve as capping agents for stabilization of the NPs (Ahmed et al.,
2016; Sultanabad et al., 2018; Ganbari et al., 2017).

Biosynthesized ZnO NPs used for antibacterial purposes have several modes of action. First, they disrupt the integrity and potential membrane of the bacteria. Secondly, the ZnO NPs form reactive oxygen species (ROS) and induce nitrogen reactive species to inhibit several specific enzymes and finally cause the death of the cell. ZnO NPs could also generate hydro-gen peroxide; penetrate and cause injury to the cell membrane and subsequently prevent the development of the cells [34]. This is as a result of the affinity between $\mathrm{ZnO}$ and bacterial cells (Dobrucka \& Dugaszewska. 2015). ZnO NPs are considered ideal potential antibacterial reagent to replace some antibiotics due to selective toxicity (Shah et al., 2015; Sumdaramurthy \& Parthiban. 2015) as well as their effective inhibition of some bacteria such as dehydrogenase (Reddy et al., 2014).

\section{Materials and Methods}

\subsection{Plant Collection}

Stem-back of Barringtonia asiatica were collected from University Malaysia Sarawak in June 2016. The fresh stem-bark of the B.asiatica plant species were dried under room conditions for two weeks and grounded into powder form before been processed for extraction.

\subsection{Preparation of Plant Extracts}

Solvent extraction method was used as a technique to get the extracts from the fresh stem-bark of the B.asiatica as reported by Fasihuddin et al. (2010). A weighed mass of $1000 \mathrm{~g}$ each of the grounded stem-bark samples was soaked in methanol in a ratio of 1:3 at room temperature for 48 hours. The mixture was filtered to obtain the filtrate using a filter paper and the residue was re-extracted 
with fresh methanol for another 48 hours and filtered. All the filtrates (extracts) were composited and rotary evaporated using Heidolph Laborota 4000 to obtain a concentrate of methanol crude extract.

\subsection{Synthesis of ZnO Nanoparticles}

ZnO NPs were prepared with some modifications. A weighed mass of $9.15 \pm$ $0.1 \mathrm{~g}(0.05 \mathrm{~mol})$ of $\mathrm{Zn}\left(\mathrm{CH}_{3} \mathrm{COO}\right)_{2} \cdot 2 \mathrm{H}_{2} \mathrm{O}$ and $2.80 \pm 0.1 \mathrm{~g}$ of $\mathrm{KOH}$ were each dissolved in $50 \mathrm{ml}$ of absolute ethanol ((HmBG Chemicals) in a $250 \mathrm{ml}$ Schott bottle and heated under $60 \pm 2{ }^{\circ} \mathrm{C}$ with constant stirring using Electric Stirring Hotplate (FAVORIT). After total dissolution of the two solutions, the $\mathrm{KOH}$ solution was drained drop wise from a burette into the $\mathrm{Zn}\left(\mathrm{CH}_{3} \mathrm{COO}\right) \cdot 2 \cdot 2 \mathrm{H}_{2} \mathrm{O}$ solution slowly at 60 $\pm 2{ }^{\circ} \mathrm{C}$ temperature with vigorous stirring in order to adjust the $\mathrm{pH}$ of the solution to 12. The stirring was done for an hour until white precipitate of zinc oxide was formed. A measured volume of $50 \mathrm{ml}$ each of the organic plant stem-bark extracts of B. asiatica from a burette were allow to drain drop wise into each mixture separately under constant stirring at $20 \pm$ $2{ }^{\circ} \mathrm{C}$ temperature with a magnetic stirrer for 3 hours. The solutions were allowed to cool at room temperature where the precipitate was separated from the supernatant by centrifuging at $4000 \mathrm{rpm}$ for 30 minutes using Fleta 5, Hanil. The solid zinc oxide precipitate was thoroughly washed and dried under hot air in an oven at a temperature of $80{ }^{\circ} \mathrm{C}$ for four hours, cooled in a desiccator before been preserved in air-tight container for characterization Umaru et al., 2018).

\subsection{Characterization and Instrumental Analysis of $\mathrm{ZnO}$ Nanoparticles}

Different characterization techniques were employed to determine the existence and purity of the synthesized ZnO NPs.

\section{UV-Vis Spectra Analysis}

The optical property of the synthesized ZnO NP sample was determined by measuring its maximum absorbance using UV-Vis spectrophotometry (UV-1800 SHIMADZU). The NPs was dispersed in $95 \%$ Absolute ethanol and sonicated for 10 minutes before the absorbance analysed in the range of 300-400 nm.

\section{Scanning Electron Microscopy Analysis}

The morphology of ZnO NPs was determined using scanning electron microscopy (SU3500, Hitachi) with spectral imaging system Thermo Scientific NSS (EDS) and detector tape (BSE-3D) with acceleration voltage of $10.0 \mathrm{kV}$, working distance of $11.6 \mathrm{~mm}$ and a pressure of $40 \mathrm{~Pa}$. Before the SEM imaging, the dry powdered solid ZnO NPs were coated on an aluminium plate with the help of adhesive membrane on the aluminium plate.

\section{Transmission Electron Microscope (TEM)} Analysis

The morphological features especially the size and shape of $\mathrm{ZnO}$ NPs was determined using TEM (JEOL JEM-1230, Japan). Dry powdered ZnO NPs were first diluted with absolute ethanol (95\%) and sonicated with ultrasonic cleaner (Elma, Germany) for 10 minutes. A volume of $4 \mu \mathrm{l}$ of the solution sample was loaded onto a Foamvar film Copper grid (FF300-Cu) before being observed under TEM.

\section{$X$-ray Diffraction (XRD) Analysis}

The biosynthesized samples from the two precursors of the plant species were characterized using X-ray Diffraction, XRD, (Xpert Pro MPD PW3040/60) for their crystal structure and crystallite size. 
Diffraction patterns from the XRD analysis were obtained using $X$-ray diffractometer with Cu-Ka radiation of $40 \mathrm{kV}$ and $30 \mathrm{~mA}$ with step size of $0.017^{\circ}$.

\section{Fourier Transform Infra-Red Spectroscopy (FT-IR) Analysis}

Surface functional groups present in the synthesized ZnO NPs was analysed using FT-IR (Thermo scientific Nicolet is 10, US) with spectral range of $4000-400 \mathrm{~cm}-1$ at a resolution of $4 \mathrm{~cm}^{-1}$. The characterization involved mixing the dry powdered $\mathrm{ZnO}$ NPs with Potassium bromide $(\mathrm{KBr})$ in a ratio of 1: 19 Yang et al., 2009). The sample was then placed in the metal hole, pressed until the sample was compressed inside the hole which was used for the analysis.

\section{Energy-dispersive X-ray Spectroscopy (EDX) Analysis}

The purity of the ZnO NPs was determined with EDX (JEOL 6390LA, Japan). The ZnO
NPs were diluted with absolute ethanol (95\%) and sonicated with ultrasonic cleaner (Elma, Germany) for 10 minutes. Then, $4 \mu \mathrm{l}$ of the liquid sample was loaded onto an aluminium plate before being analysed with the EDX.

\section{Atomic Absorption Spectroscopy (AAS) Analysis}

Confirmation of the presence of Zinc in the synthesized samples was carried out using AAS. A known concentration of the sample was prepared and analysed for the presence of the elemental Zinc using AAS (iCE 3000 Series AA, Thermo Scientific). Air-acetylene was used as fuel at approximately $2300{ }^{\circ} \mathrm{C}$ and flowed at $0.9 \mathrm{~L} / \mathrm{min}$. Doubled-beam optics with monochromator reduced the detection limits and provided higher accuracy. The various parameters used in the analysis are illustrated in Table 1.

Table 1: AAS parameters used in the analysis of the synthesized $\mathrm{ZnO}$ samples

\begin{tabular}{|l|l|}
\hline Parameter & Characteristics \\
\hline Wavelength $(\mathrm{nm})$ & 213.9 \\
\hline Flame type & Air-C2H2 \\
\hline Nebulizer uptake $(\mathrm{s})$ & 4 \\
\hline Burner height $(\mathrm{mm})$ & 14.2 \\
\hline Lamp current $(\%)$ & 75 \\
\hline Rescale limit $(\%)$ & 10 \\
\hline Standards $(\mathrm{mg} / \mathrm{L})$ & $0.3000,0.6000$ and 1.000 \\
\hline Acceptable fit & 0.995 \\
\hline Detection limit $(\mathrm{mg} / \mathrm{L})$ & 0.0033 \\
\hline
\end{tabular}

\subsection{Preparation of Test Samples}

The synthesized $\mathrm{ZnO}$ nanoparticle was tested using disc diffusion method on nutrient agar medium Umaru et al., 2018). The preparation of test samples follows the procedure reported by, , Umaru et al. (2019) where $1000 \mathrm{mg} / \mathrm{mL}$ stock sample from the synthesized $\mathrm{ZnO}$ sample was prepared and from which serial diluted concentrations of $25,50,100,250,500$, and $1000 \mathrm{\mu g} / \mathrm{ml}$ were obtained for the study.

\subsection{Preparation of Bacteria Broth}

The bacteria used for the activity of the biosynthesized ZnO NPs were obtained from the stock culture provided by Virology Laboratory, UNIMAS (Universiti Malaysia Sarawak). The procedure for bacteria broth preparation follows the one reported by, Umaru et al. (2020) where a weighed mass of $2.60 \mathrm{~g}$ of the dried broth was dissolved (in $200 \mathrm{~mL}$ deionized water) and autoclave at a temperature of $121^{\circ} \mathrm{C}$. The bacterial was incubated with a shaker at a temperature of $37{ }^{\circ} \mathrm{C}$, Umaru et al. 
(2018b) for $16 \mathrm{~h}$. The optical density (OD) of the bacterial broth after incubation was computed by UV Mini Spectrophotometer (1240 SHIMADZU) at wavelength $575 \mathrm{~nm}$ and compared to the standard (0.6-0.9).

\subsection{Plate Inoculation}

Inoculation of the bacteria for this study follows the procedure reported by Umaru et al. (2020) where $1 \mathrm{~mL}$ of the prepared broth was streaked over the entire agar plate surface in four different directions using sterile cotton bud. A $10 \mu \mathrm{L}$ volume of the organic test extract of concentrations 25,50, 100, 250, 500 and $1000 \mu \mathrm{g} / \mathrm{mL}$ were each pupated onto the prepared discs $(6 \mathrm{~mm}$ diameter) and gently pressed onto the agar plate and left for $10 \mathrm{~min}$ at room temperature. A pupated disc with methanol and $30 \mathrm{\mu g}$ of chloramphenicol were used as negative and positive controls respectively. Each of the test samples were tested in triplicate for the bacterium used. The plate samples were then incubated at a temperature of $37^{\circ} \mathrm{C}$ for $24 \mathrm{~h}$ before the inhibition zone around every sample disc being examined. The inhibition zone was computed in diameter $(\mathrm{mm})$ to show the presence of antibacterial activity for all the samples compared to the positive control.

\subsection{Statistical Analysis}

The inhibition zone diameter data were computed using one-way analysis of variance (ANOVA) with differences considered at $P$ value $<0.05$

\section{RESULTS AND DISCUSSIONS Morphological Analysis UV-Vis Analysis}

Figure 1 displays the UV-Visible absorption spectrum of synthesized ZnO NPs from methanol extracts of B- asiatica using $\mathrm{ZnCl}_{2}$ and $\left(\mathrm{ZnCH}_{3} \mathrm{COO}\right)_{2} \cdot 2 \mathrm{H}_{2} \mathrm{O}$ as precursor in the range of $300-400 \mathrm{~nm}$. Mohammadi-Aloucheh et al., 2018; Shankar \& Rhim. 2017).
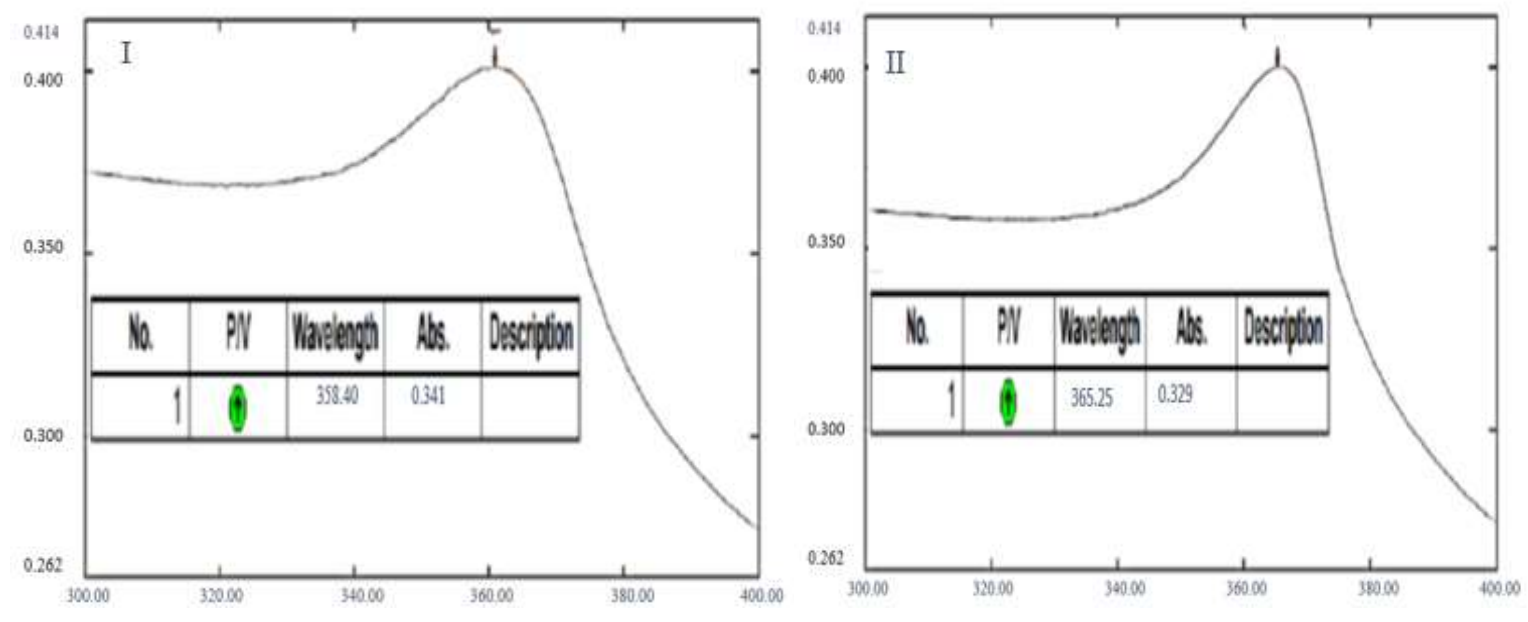

Figure 2: UV-Visible spectra of $\mathrm{ZnO}$ NPs synthesized with $\mathrm{ZnCl}_{2}$ (I) and $\mathrm{Zn}\left(\mathrm{CH}_{3} \mathrm{COO}\right)_{2} \cdot 2 \mathrm{H}_{2} \mathrm{O}$ (II) from methanol extract of B. asiatica stem-bark.

In this our study, the results showed the absorption peak for the synthesized ZnO NPs to be in conformity with the range of light absorption of ZnO NPs, which is $360-380 \mathrm{~nm}$, this also agree with the report of Nagarajan \& Arumugam. (2013).

\section{SEM Analysis}

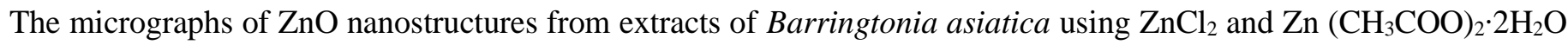
as precursor showed high aggregation of NPs with spherical shape (Fig 3) as similar to structures documented by Shadrokh et al. (2007) 

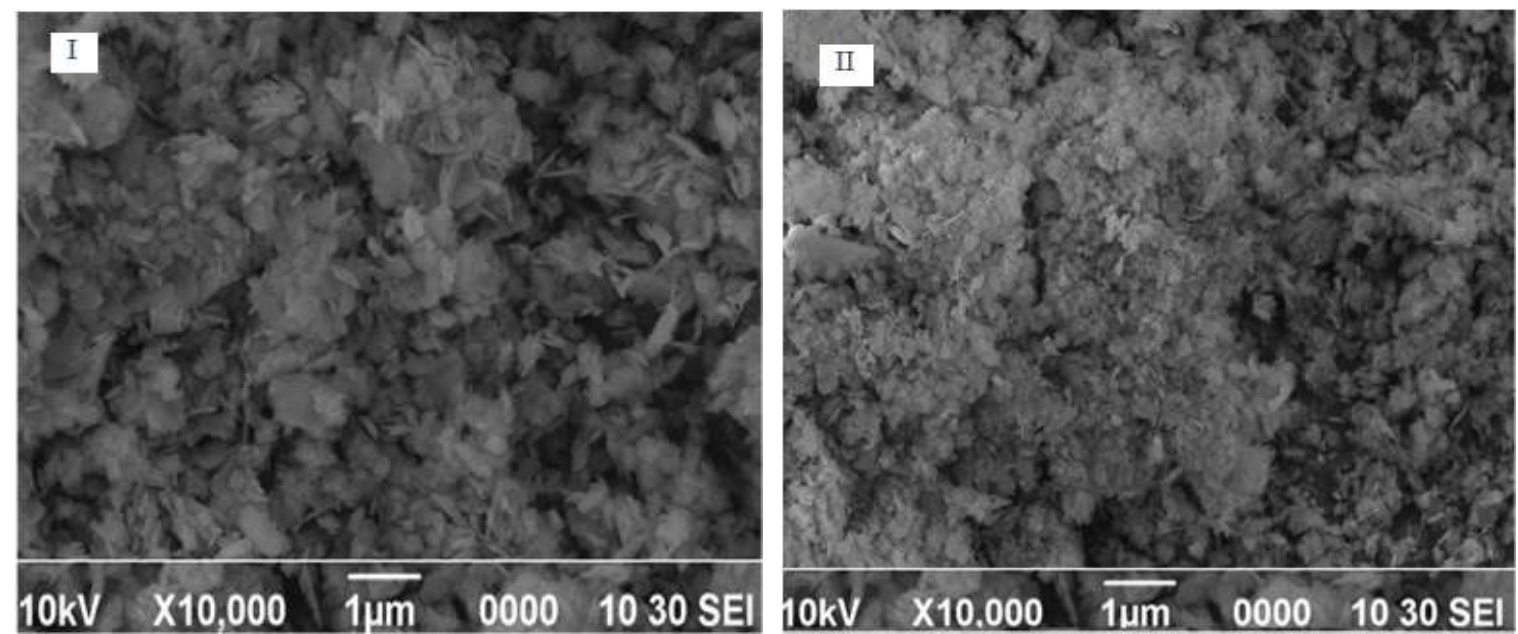

\section{$10 \mathrm{kV} \times 10,000 \quad \overline{1 \mu \mathrm{m}} 0000 \quad 1030$ SEI $10 \mathrm{kV} \times 10.000 \quad \overline{1 \mathrm{um}} 0000 \quad 1030$ SEI}

Figure 3: $\mathrm{SEM}$ micrographs of $\mathrm{ZnO}$ nanostructures synthesized with $\mathrm{ZnCl}_{2}$ (I) and $\mathrm{Zn}\left(\mathrm{CH}_{3} \mathrm{COO}\right)_{2} \cdot 2 \mathrm{H}_{2} \mathrm{O}$ (II) from ethanol extract of $B$. asiatica

The result of the SEM analysis showed that the stem-bark crude extract affected the shape of the nanoparticles produced. The aggregation is assumed to be due to the polarity and the electrostatic attraction of $\mathrm{ZnO}$ nanoparticles as reported by Divya et al. (2013). This also agrees with the study of Vaccinium arctostaphylos L. fruit extract which was used in synthesizing ZnO NPs using zinc nitrate as precursor, nearly spherical shaped structures were produced (Mohammadi-Aloucheh et al., 2018)

\section{TEM Analysis}
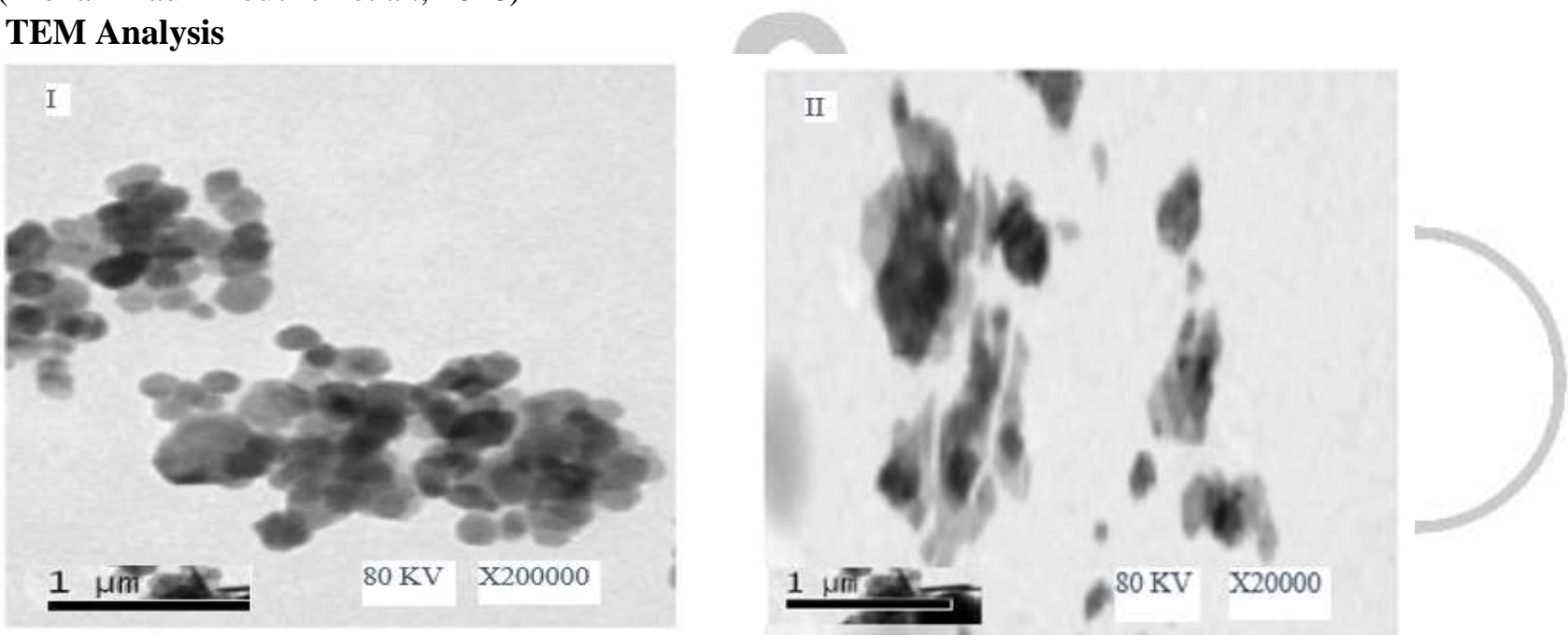

Figure 4: TEM image of $\mathrm{ZnO}$ nanostructure synthesized with $\mathrm{ZnCl}_{2}$ (I) and $\mathrm{Zn}\left(\mathrm{CH}_{3} \mathrm{COO}\right)_{2} \cdot 2 \mathrm{H}_{2} \mathrm{O}$ (II) from methanol extract of B. asiatica stem-bark.

The TEM result conforms to the result obtained by similar studies by Geetha et al. (2016). On the other hand, $\mathrm{ZnO}$ NPs synthesized from B.asiatica using the two precursors gave irregularly shaped structures of polyhedron (Fig 4 I \& II) as similar to results by Zheng et al. (2015), when Corymbia citriodora leaf extract was used in the synthesis of $\mathrm{ZnO}$. The average particle size realised in this study for the above samples were $70.11 \mathrm{~nm}$ and $83.76 \mathrm{~nm}$ for $\mathrm{ZnCl}_{2}$ and $\mathrm{Zn}\left(\mathrm{CH}_{3} \mathrm{COO}\right)_{2} \cdot 2 \mathrm{H}_{2} \mathrm{O}$ respectively which was in line with reported particle sizes determined by Daphedar \& Taranath. (2018) and Khatami et al. (2018).

\section{XRD results}



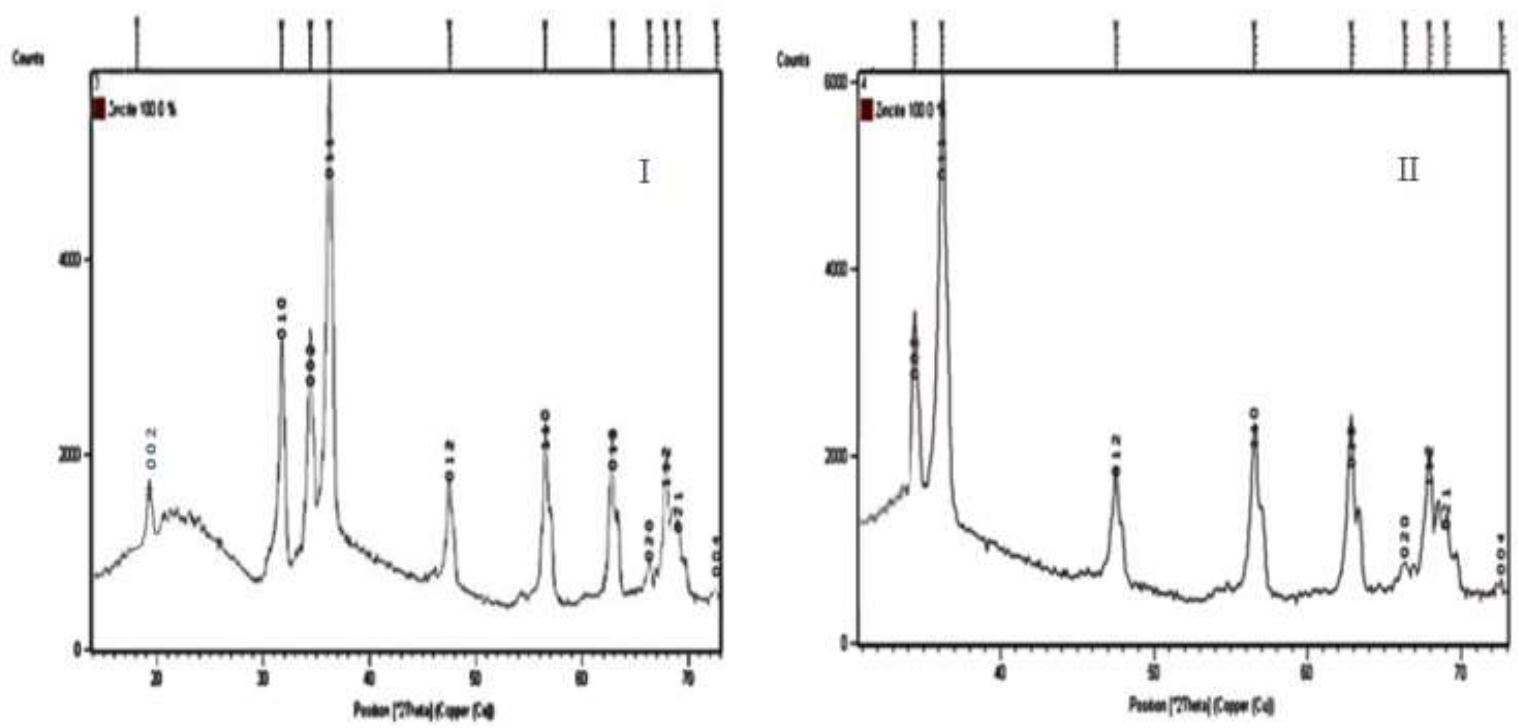

Figure 5: XRD patterns of $\mathrm{ZnO}$ nanostructures synthesized with $\mathrm{ZnCl}_{2}$ (I) and $\mathrm{Zn}\left(\mathrm{CH}_{3} \mathrm{COO}\right){ }_{2} \cdot 2 \mathrm{H}_{2} \mathrm{O}$ (II) from methanol extract of $B$. asiatica stem-bark

Table 2: Average crystallite size calculation for B. asiatica extracts with $\mathrm{ZnCl}_{2}$ as precursor

\begin{tabular}{|l|l|l|l|}
\hline $2 \Theta$ & hkl & $\begin{array}{l}\text { FWHM } \\
(\beta)\end{array}$ & D (nm) \\
\hline 31.8 & 010 & 0.3637 & 22.16332 \\
\hline 34.7 & 002 & 0.5933 & 13.61352 \\
\hline 36.4 & 011 & 0.6597 & 10.74534 \\
\hline 47.8 & 012 & 0.4456 & 16.33426 \\
\hline 56.8 & 110 & 0.6396 & 11.36674 \\
\hline 62.9 & 013 & 0.2598 & 26.33425 \\
\hline 68.0 & 112 & 1.2672 & 4.886735 \\
\hline Average crystallite size $=15.06$ & & \\
\hline
\end{tabular}

Table 3: Average crystallite size calculation for B. asiatica $\mathrm{Zn}\left(\mathrm{CH}_{3} \mathrm{COO}\right)_{2} \cdot 2 \mathrm{H}_{2} \mathrm{O}$ as precursors.

\begin{tabular}{|l|l|l|l|}
\hline $2 \Theta$ & hkl & $\begin{array}{l}\text { FWHM } \\
(\beta)\end{array}$ & D (nm) \\
\hline 31.6 & 010 & 0.2897 & 26.44452 \\
\hline 34.3 & 002 & 0.4633 & 17.32335 \\
\hline 36.1 & 011 & 0.5246 & 13.89947 \\
\hline 47.3 & 012 & 0.3412 & 21.78696 \\
\hline 56.5 & 110 & 0.3938 & 18.44633 \\
\hline 62.7 & 013 & 0.5196 & 13.42353 \\
\hline 67.7 & 113 & 0.6336 & 11.12318 \\
\hline \multicolumn{4}{|l}{} \\
\hline
\end{tabular}


X-ray diffraction was further conducted to confirm the $\mathrm{ZnO}$ phase of the nanoparticles. The patterns are shown in Figure 4 where the FWHM value for every peak assigned for particle size calculation are also shown in Table 1. The crystallite size of the nanostructures was obtained using Debye-Scherer's formula;

$\mathrm{D} \quad=\frac{K \lambda}{(\beta \cos \theta)}$

(1)

$B=\sqrt{ } \beta^{2} F W H M-\beta^{2} 0$

Where; D - crystallite size, - wavelength of radiation, $K$ - shape factor $=0.89, \beta$-the peak broadening after removing the instrumental broadening, $\beta$ (FWHM) is the full width half maximum of the diffraction peak and $\beta 0$ is the correction factor for instrumental broadening $(0.07 \circ 2 \theta)$. All detectable peaks can be indexed to ZnO wurtzite structure with ICSD Number (ICSD: 98-000-9346) and PDF Number (Experimental and calculated powder diffraction data) of 35-1451 and 01-0750535 respectively.

The average crystallite size of $\mathrm{B}$. asiatica extracts with $\mathrm{ZnCl}_{2}$ and $\mathrm{Zn}\left(\mathrm{CH}_{3} \mathrm{COO}\right)$ $2 \cdot 2 \mathrm{H}_{2} \mathrm{O}$ as precursors $\mathrm{ZnO}$ was found to be $15.06 \mathrm{~nm}$ and $17.49 \mathrm{~nm}$

\section{FTIR results}

FTIR was employed for the determination of the functional groups on the biosynthesized ZnO NPs in the range of $400-4000 \mathrm{~cm}-1$ as illustrated in Figure 5 and Figure 6.
The presence of functional groups such as alcohols, phenols, amines, carboxylic acids from the organic extract from the FTIR results can interact with the zinc surface and aid in the stabilization of particles. The spectra peaks observed between $440-458 \mathrm{~cm}^{-1}$ corresponds to the ZnO bond stretching vibrations for all the synthesized samples.

The broad absorption peaks was observed at $3745.91-3012.74 \mathrm{~cm}^{-1}$ in the sample represent the stretching vibration mode of $-\mathrm{OH}$ groups. Though, the peaks are very strong in the case of ZnO NPs synthesized with $\mathrm{ZnCl}_{2}$ (Fig 5), similar peaks were observed in $\mathrm{ZnO}$ NPs synthesized with $\mathrm{Zn}\left(\mathrm{CH}_{3} \mathrm{COO}\right)_{2} \cdot 2 \mathrm{H}_{2} \mathrm{O}$ (Fig 6). This could be as a result of same concentration levels of phytochemical compounds present in the plant species. Table 4 summarizes the different absorption peaks identified compared with some previous studies. 


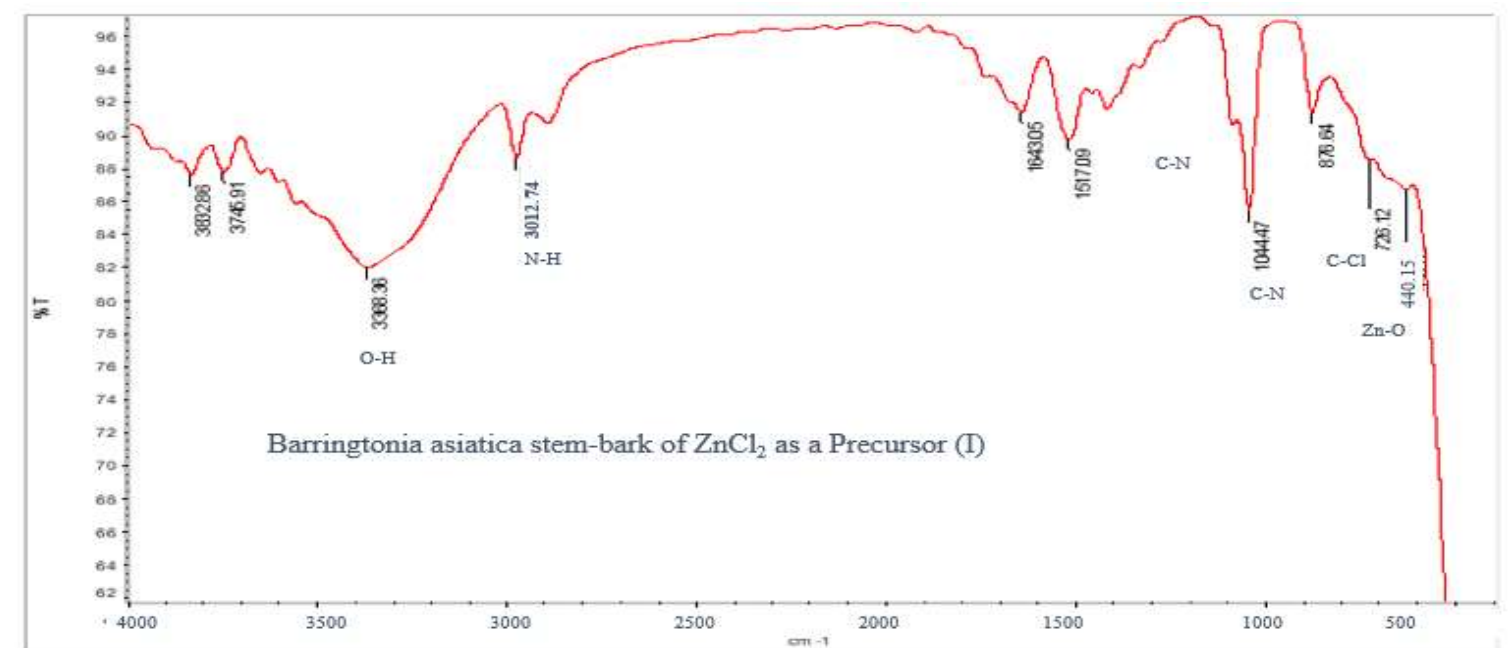

Figure 6: FT-IR spectra of $\mathrm{ZnO}$ NPs synthesized with $\mathrm{ZnCl}_{2}$ from methanol extract of B. asiatica stem-bark

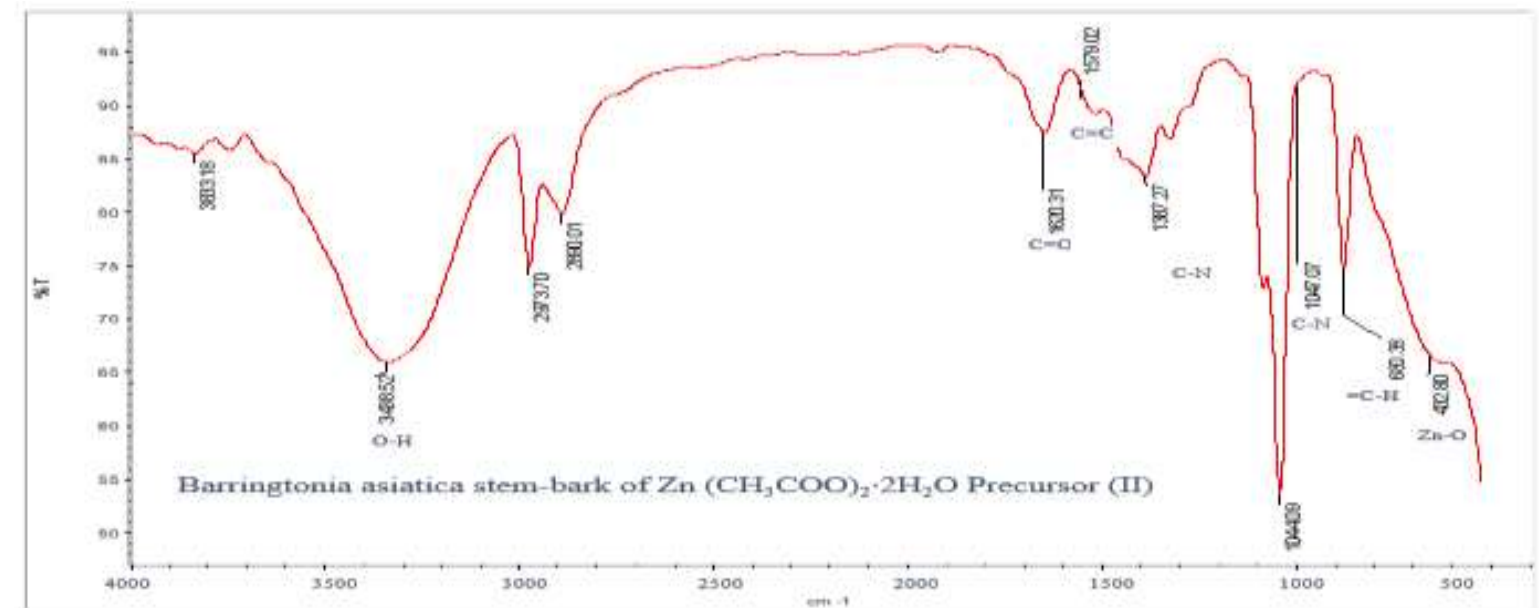

Figure 7: FT-IR spectra of $\mathrm{ZnO}$ NPs synthesized with $\mathrm{Zn}\left(\mathrm{CH}_{3} \mathrm{COO}\right)_{2} \cdot 2 \mathrm{H}_{2} \mathrm{O}$ from methanol extract of $\mathrm{B}$. asiatica stem-bark.

Table 4: FT-IR spectral peaks of synthesized $\mathrm{ZnO}$ NPs from methanol extracts of stem-bark of B. asiatica using $\mathrm{ZnCl}_{2}$ and $\mathrm{Zn}\left(\mathrm{CH}_{3} \mathrm{COO}\right)_{2} \cdot 2 \mathrm{H}_{2} \mathrm{O}$ as precursor.

\begin{tabular}{|l|l|l|l|l|l|l|l|l|l|l|}
\hline Plant & Zn-O & C-Cl & C-N & $\mathbf{C}=\mathbf{C}$ & $\mathbf{C = O}$ & $\mathbf{N}-\mathbf{H}$ & $\mathbf{=}$ C-H & $\mathbf{C}-\mathbf{C}$ & $\mathbf{O}-\mathbf{H}$ & Ref \\
\hline $\begin{array}{l}\text { B.asiatica stem-bark } \\
\mathrm{ZnCl}_{2}\end{array}$ & 440.15 & 728.12 & 1044.47 & & & 3012.72 & & & 3388.36 & study \\
\hline $\begin{array}{l}\text { B.asiatica stem-bark } \\
\mathrm{Zn}\left(\mathrm{CH}_{3} \mathrm{COO}\right)_{2} \cdot 2 \mathrm{H}_{2} \mathrm{O}\end{array}$ & 432.80 & & 1047.07 & 1579.02 & 1630.31 & & 680.38 & & 3485.52 & study \\
\hline $\begin{array}{l}\text { Corymbia citriodora } \\
\text { leaves }\end{array}$ & - & - & $\begin{array}{l}1053 \\
\text { (Amine) }\end{array}$ & 1520 & - & 1620 & - & 1431 & 3300 & $(43)$ \\
\hline $\begin{array}{l}\text { Trifolium pretense } \\
\text { flower }\end{array}$ & 515 & - & - & 2168 & 1383 & - & - & - & 2345 & $(34)$ \\
\hline
\end{tabular}

\section{EDX and AAS Analysis}

The elemental composition of the synthesized ZnO NPs revealed the presence of $\mathrm{Zn}, \mathrm{O}$ and $\mathrm{C}$ as the main constituents in the samples. Although some traces of Chlorine could be identified in (Fig 7) which may be due to effect of the constituents of the $\mathrm{ZnCl}_{2}$ and $\mathrm{Zn}\left(\mathrm{CH}_{3} \mathrm{COO}\right)_{2} \cdot 2 \mathrm{H}_{2} \mathrm{O}$ precursor. From the analysed samples, the average component of $\mathrm{Zn}, \mathrm{O}$ and $\mathrm{C}$ present was $65.78 \%, 16.38 \%, 11.86 \%$ and $70.49 \%$, $15.32 \%, 12.26 \%$ from the two precursor respectively as illustrated in Table 3 . This 
result is in conformity with the study by Mohammadi-Aloucheh et al. (2018). The AAS detected elemental Zinc at $214.8 \mathrm{~nm}$ wavelength indicating the presence of the $\mathrm{ZnO}$ in the synthesized NPs. The calculated average percentage weight of $\mathrm{Zn}$ in the analysed samples using AAS technique was $72.16 \%$.
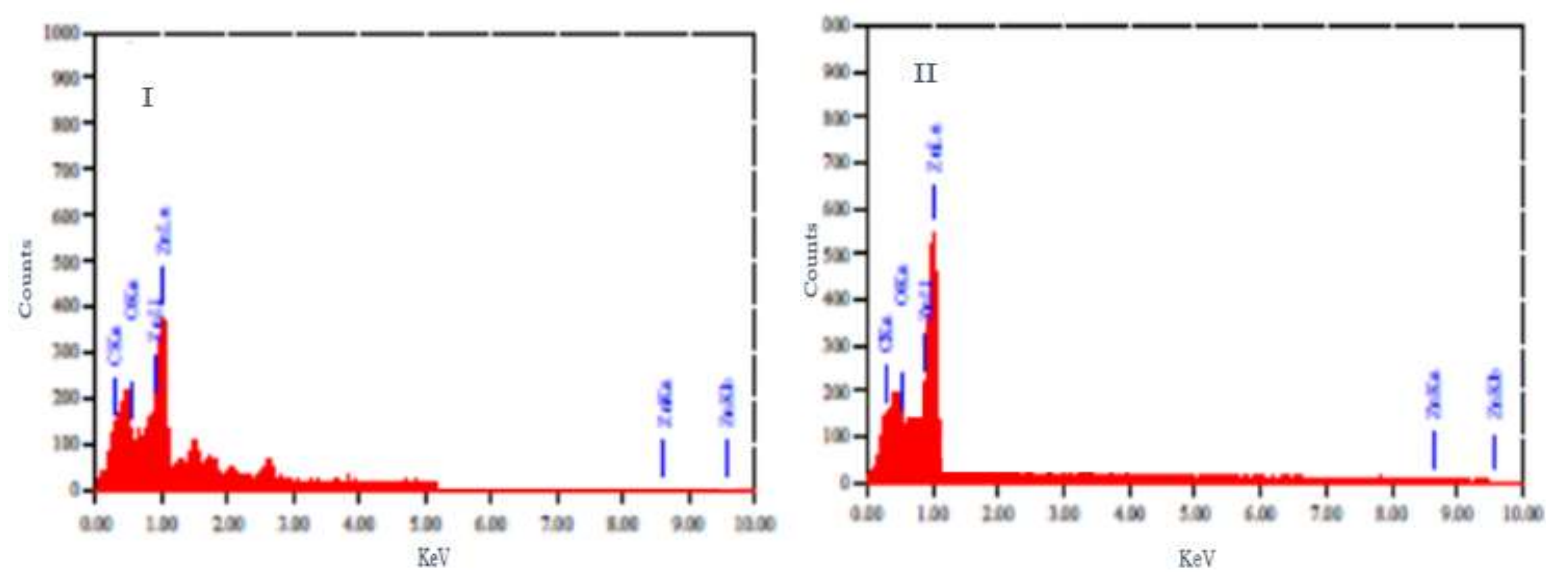

Figure 8: $\mathrm{EDX}$ analyses of $\mathrm{ZnO} \mathrm{NPs}$ synthesized with $\mathrm{ZnCl}_{2}$ from methanol extract of $B$. asiatica stem-bark

Table 3: Elemental composition of synthesized $\mathrm{ZnO}$ NPs of B. asiatica stem-bark

\begin{tabular}{|l|l|l|l|}
\hline Sample & $\mathrm{Zn} \%$ & $\mathrm{O} \%$ & $\mathrm{C} \%$ \\
\hline B. asiatica stem-bark $(\mathrm{ZnCl} 2)$ & 65.78 & 16.38 & 11.86 \\
\cline { 2 - 4 } B. asiatica stem-bark $\left(\mathrm{Zn}\left(\mathrm{CH}_{3} \mathrm{COO}\right)_{2} \cdot 2 \mathrm{H}_{2} \mathrm{O}\right)$ & 70.49 & 15.32 & 12.26 \\
\hline
\end{tabular}

\section{Antibacterial potentials}

The zone of inhibition against the selected bacterial result of the activity of the ZnO NPs is as shown in Tables 4 and 5 . 
Table 4: Effect of B. asiatica zinc chloride ( $\mathrm{ZnO})$ nanoparticle from Stem-bark extract on Escherichia coli (Gram-ve), Staphylococcus aureus, (Gram +ve), Pseudomonas aeruinosa (Gram-ve), Bcillus anthracis (Gram+ve) and Klebsielia Pneumonia (Gram +ve): Precursor $\mathrm{ZnCl}_{2}$

\begin{tabular}{|l|l|l|l|l|l|l|}
\hline \multicolumn{9}{|c|}{ Extract } \\
\hline Concentration $(\mu \mathrm{g} / \mathrm{ml})$ & Plant Part & E. coli $-v e$ & S. aureus, $+v e$ & P. aeruinosa $-\mathrm{ve}$ & B. anthracis + ve & K. Pneumonia + ve \\
\hline & Control & $3.00 \pm 1.11$ & $3.00 \pm 1.05$ & $3.12 \pm 0.03$ & $3.10 \pm 0.22$ & $3.09 \pm 0.23$ \\
\hline 50 & Stem bark & $0.33 \pm 0.06$ & $0.83 \pm 0.06^{\mathrm{a}}$ & $0.34 \pm 0.22$ & $0.50 \pm 0.13$ & $0.34 \pm 0.11$ \\
\hline 100 & Stem bark & $1.33 \pm 0.17$ & $1.37 \pm 0.15^{\mathrm{a}}$ & $0.69 \pm 0.11$ & $0.60 \pm 0.14$ & $0.57 \pm 0.13$ \\
\hline 250 & Stem bark & $1.89 \pm 0.10$ & $2.41 \pm 0.13^{\mathrm{a}}$ & $0.87 \pm 0.11$ & $0.95 \pm 0.05$ & $0.77 \pm 0.13$ \\
\hline 500 & Stem bark & $2.47 \pm 0.12$ & $3.53 \pm 0.11^{\mathrm{a}}$ & $1.52 \pm 0.15$ & $1.33 \pm 0.15$ & $0.94 \pm 0.27$ \\
\hline 1000 & Stem bark & $2.79 \pm 0.19$ & $3.83 \pm 0.16^{\mathrm{a}}$ & $2.53 \pm 0.17$ & $1.68 \pm 0.16$ & $1.14 \pm 0.06$ \\
\hline
\end{tabular}

Values are Mean \pm SD for three determinations

a Significantly $(p<0.05)$ higher compared at the same concentration in each row

bSignificantly $(\mathrm{p}<0.05)$ higher compared at the same concentration in each column

Table 5: Effect of B. asiatica zinc chloride ( $\mathrm{ZnO})$ nanoparticle from Stem-bark extract on Escherichia coli (Gram-ve), Staphylococcus aureus, (Gram+ve),

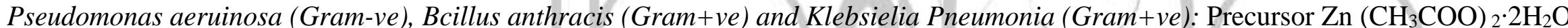

\begin{tabular}{|l|l|l|l|l|l|l|}
\hline \multicolumn{5}{|l|}{} & \multicolumn{5}{c|}{ Extract } \\
\hline Concentration $(\mu \mathrm{g} / \mathrm{ml})$ & Plant Part & E. coli - ve & S. aureus, + ve & P. aeruinosa $-\mathrm{ve}$ & B. anthracis + ve & K. Pneumonia $+v e$ \\
\hline & Control & $3.00 \pm 1.11$ & $3.00 \pm 1.05$ & $3.12 \pm 0.03$ & $3.10 \pm 0.22$ & $3.09 \pm 0.23$ \\
\hline 25 & Stem bark & $0.42 \pm 0.04$ & $0.66 \pm 0.14^{\mathrm{a}}$ & $0.57 \pm 0.13$ & $0.45 \pm 0.14$ & $0.56 \pm 0.22$ \\
\hline 50 & Stem bark & $0.53 \pm 0.34$ & $0.93 \pm 1.13$ & $0.77 \pm 0.18^{\mathrm{a}}$ & $0.67 \pm 0.05$ & $0.99 \pm 0.12^{\mathrm{a}}$ \\
\hline 100 & Stem bark & $0.73 \pm 0.07$ & $1.47 \pm 0.17$ & $1.44 \pm 0.16^{\mathrm{a}}$ & $0.88 \pm 0.21$ & $1.57 \pm 0.16^{\mathrm{a}}$ \\
\hline 250 & Stem bark & $0.99 \pm 0.19$ & $2.53 \pm 0.15^{\mathrm{a}}$ & $2.10 \pm 0.17$ & $1.19 \pm 0.19$ & $2.11 \pm 0.12$ \\
\hline 500 & Stem bark & $1.17 \pm 0.13$ & $2.55 \pm 0.14$ & $2.55 \pm 0.10$ & $1.57 \pm 0.15$ & $2.58 \pm 0.06^{\mathrm{a}}$ \\
\hline 1000 & Stem bark & $1.59 \pm 0.18^{\mathrm{b}}$ & $2.86 \pm 0.08^{\mathrm{b}}$ & $3.59 \pm 0.12^{\mathrm{b}}$ & $2.58 \pm 0.09^{\mathrm{b}}$ & $3.20 \pm 0.10^{\mathrm{b}}$ \\
\hline
\end{tabular}

Values are Mean \pm SD for three determinations

aSignificantly $(\mathrm{p}<0.05)$ higher compared at the same concentration in each row
${ }^{\text {b}}$ Significantly
( $\mathrm{p}<$
0.05) higher
compared
at
the
same
concentration
in
each
column

2021 May Edition | www.jbino.com | Innovative Association 
During the past two decades the research for biosynthesized nanotechnology for reliable antimicrobial medication was accelerated because of the increased cases of resistant of bacterial, viral strains against medication. Resistance of bacterial strains against antibiotic and on the other hand, characteristic exhibited by nanoparticles such as small size, surface area, surface reactivity, charge and shape necessitated for the study to produce biosynthesized drugs.

From the results of $\mathrm{ZnCl}_{2}$ and $\mathrm{Zn}$ $\left(\mathrm{CH}_{3} \mathrm{COO}\right)_{2} \cdot 2 \mathrm{H}_{2} \mathrm{O}$ as precursor of $\mathrm{B}$. asiatica nanoparticles, inhibition of selected bacteria increased with increasing concentration $(25-1000 \mu \mathrm{g} / \mathrm{ml})$. From Table 4 staphylococcus aureus recorded the highest inhibition of $3.99 \pm$ $0.17 \mathrm{~mm}$ at $1000 \mu \mathrm{g} / \mathrm{ml}$ of Barringtonia asiatica stem-bark of $\mathrm{ZnCl}_{2}$ precursor. Conversely Bacillus anthraces (Gram+ve) recorded the least inhibition of $2.39 \pm 0.13$ $\mathrm{mm}$ with increasing concentration. From Table $5 \mathrm{ZnO}$ NPs from $\mathrm{Zn}\left(\mathrm{CH}_{3} \mathrm{COO}\right)$ $2 \cdot 2 \mathrm{H}_{2} \mathrm{O}$ as a precursor gave an inhibition $3.59 \pm 0.12 \mathrm{~mm}$ in Pseudomonas aeruinosa (Gram -ve), higher than the control and least inhibition was observed of $1.59 \pm$ $0.18 \mathrm{~mm}$ in Escherichia coli with increasing concentration from at 1000 $\mu \mathrm{g} / \mathrm{ml}$.

In the case of Gram-negative bacterial used in this study Pseudomonas aeruinosa was reported to have higher inhibition among the two precursors used. The variation in morphological compositions between the Gram -ve and Gram +ve bacteria may be the factor for the variations in microbes (antibacterial) sensitivity. Moreover, concentration and nature of the ZnO NPs has tremendous impact on the activity of the bacterial resulting in the damaging of the membrane and cytoplasmic contents (Divyapriya et al., 2014). It may be that the binding capacity of chemical constituents to the precursor and the antioxidant contents varies.

\section{Conclusions}

This paper details the synthesis of $\mathrm{ZnO}$ and $\mathrm{Zn}\left(\mathrm{CH}_{3} \mathrm{COO}\right)_{2} \cdot 2 \mathrm{H}_{2} \mathrm{O}$ NPs through green chemistry using Barringtonia asiatica stem-bark extract which confirm the presence of $\mathrm{ZnO}$ in samples through FT-IR, AAS, XRD, and UV-Vis techniques. Morphologically the SEM micrograph recorded spherical and flake-like Nanostructure. While the TEM recorded a fair with an average particle size of 44.36 $\mathrm{nm}$ and $33.16 \mathrm{~nm}$ for $\mathrm{ZnCl}_{2}$ and $\mathrm{Zn}$ ( $\mathrm{CH} 3 \mathrm{COO}) 2 \cdot 2 \mathrm{H}_{2} \mathrm{O}$ respectively. On the other hand, crystallite size from XRD analysis was in the range of 14.69-84.26 $\mathrm{nm}$. The crystallite size and the homogeneity of the $\mathrm{ZnO}$ and $\mathrm{Zn}$ $\left(\mathrm{CH}_{3} \mathrm{COO}\right)_{2} \cdot 2 \mathrm{H}_{2} \mathrm{O}$ were influenced by the amount of extract used during the synthesis. Using the two precursors, $\mathrm{ZnCl}_{2}$ and $\mathrm{Zn}\left(\mathrm{CH}_{3} \mathrm{COO}\right) 2 \cdot 2 \mathrm{H}_{2} \mathrm{O}$ gave a good antimicrobial activity. The results proved that the methanol extract $B$. asiatica stem-bark sampled which was biologically synthesized with $\mathrm{ZnO} \mathrm{NPs}$ using two precursors $\left(\mathrm{ZnCl}_{2}\right.$ and $\mathrm{Zn}$ $\left.\left(\mathrm{CH}_{3} \mathrm{COO}\right) 2 \cdot 2 \mathrm{H}_{2} \mathrm{O}\right)$ showed potential antibacterial activity especially in Staphylococcus aureus recorded the highest inhibition of $3.99 \pm 0.17 \mathrm{~mm}$ and 
Pseudomonas aeruinosa (Gram -ve) of $3.59 \pm 0.12 \mathrm{~mm}$, higher than the control.

\section{Acknowledgement}

The author acknowledge Natural Product Lab, University Malaysia Sarawak and Central Lab Federal University Wukari.

\section{References}

1. Baltz, R. H. (2017). Gifted microbes for genome mining and natural product discovery. Journal of Industrial Microbiology \& Biotechnology, 44(4-5), 573-588.

2. Raymond, C., \& George, N. (2015). Natural Products Chemistry. Sources, separations, and structures, Taylor \& Francis Group 6000 Broken Sound Parkway NW, Suite 300 Boca Raton, FL 33487.

3. Alfrits Komansilan., \& Ni Wayan Suriani. (2016). Effectiveness of seed extract hutun (Barringtonia asiatica Kurz), on larva Aedes aegypti vector disease dengue fever. International Journal of Chemistry and Technology Research, 9(4), 617-624.

4. Tanor, M. N., Abadi, A. L., Rahardjo, B. T., \& Pelealu, J. (2014). Isolation and Identification of Triterpenoid Saponin from Baringtonia asiatica Kurz Seeds. Journal of Tropical Life Science, 4(2), 119-122.

5. Umaru, I. J., Ahmed, F. B., Umaru, H. A., \& Umaru, K. I. (2018). Barringtonia racemosa: Phytochemical,

pharmacological,

biotechnological, botanical, traditional use and agronomical aspects. World Journal of Pharmacy and Pharmaceutical Science, 7(8), 78-121.

6. Jones, K. E., Patel, N. G., Levy, M. A., Storeygard, A., Balk, D., Gittleman, J. L.,
Daszak, P., (2008). "Global trends in emerging infectious diseases", Nature, 451 (7181): 990-993.

7. Khan, S. T., Musarrat, J., Al-Khedhairy, A. A., (2016). "Countering drug resistance, infectious diseases, and sepsis using metal and metal oxides nanoparticles, current status", Colloids Surf B Biointerfaces, 146: 70-83.

8. Kumar, R.., Umar, A., Kumar, G., Nalwa, H. S., (2017). "Antimicrobial properties of ZnO nanomaterials: a review", Ceram Int., 43: 3940-3961.

9. Yah, C. S., Simate, G. S., (2015). "Nanoparticles as potential new generation broad spectrum antibacterial agents", DARU Journal of Pharmaceutical Sciences, 23(1): 43.

10. Vimbela, G. V., Ngo, S. M., Fraze, C., Yang, L., Stout, D. A., (2017). "Antibacterial properties and toxicity from metallic nanomaterials", International journal of nanomedicines, 12: 3941.

11. Nowack, B., Bucheli, T. D., (2007). "Occurrence, behavior and effects of nanoparticles in the environment", Environmental pollution, 150(1): 522.

12. Bhattacharya, R., Mukherjee, P., (2008). "Biological properties of naked metal nanoparticles", Advanced Drug Delivery Reviews, 60(11): 1289-1306.

13. Sharma, V. K., Yngard, R. A., Lin, Y., (2009). "Silver nanoparticles: green synthesis and their antibacterial activities", Advances in colloid and interface science, 145(1-2): 83-96.

14. Shah, M., Fawcett, D., Sharma, S., Tripathy, S. K., Poinern, G. E. J., (2015). "Green synthesis of metallic nanoparticles via biological entities", Materials, 8(11): 7278-7308. 
15.Stankic, S., Suman, S., Haque, F., Vidic, J., (2016). "Pure and multi metal oxide nanoparticles: synthesis, antibacterial and cytotoxic properties", J. Nanobiotechnol., 14(1): 73.

16. Nel, A., Xia, T., Mädler, L., Li, N., (2006). "Toxic potential of materials at the nanolevel", Science, 311 (5761): 622-627.

17.Singh, B. N., Rawat, A. K. S., Khan, W., Naqvi, A. H., Singh, B. R., (2014). "Biosynthesis of stable antioxidant $\mathrm{ZnO}$ nanoparticles by Pseudomonas aeruginosa rhamnolipids", PLOS One, 9 (9): 106937.

18. Peralta-Videa, J. R., Huang, P. Y., Parsons, J., Zhao, L., Lopez-Moreno, L., HernandezViezcas, J. A., Gardea-Torresdey, J. L., (2016). "Plant-based green synthesis of metallic nanoparticles: scientific curiosity or a realistic alternative to chemical synthesis?", Nanotechnol Environ Eng., $1(1): 4$.

19. Hu, S-H., Chen, Y-C., Hwang, C-C., Peng, C-H., Gong, D-C., (2010). "Development of a wet chemical method for the synthesis of arrayed "ZnO nanorods", J. Alloy. Comp., 500 (2): L17-L21.

20. Wang, A., Ng, H. P., Xu, Y., Li, Y., Zheng, Y., Yu, J., Han, F., Peng, F., Fu, L., (2014). "Gold nanoparticles: synthesis, stability test, and application for the rice growth", J. Nanomater., Article ID 451232.

21.Chen, Y., Zhang, C., Huang, W., Situ, Y., Huang, H., (2015). "Multimorphologies nano-ZnO preparing through a simple solvothermal method for photocatalytic application", Mater. Lett., 141: 294-297.

22. Tien, H. N., Khoa, N., Hahn, S. H., Chung, J. S., Shin, E. W., Hur, S. H., (2013). "One-pot synthesis of a reduced graphene oxide zinc oxide sphere composite and its uses as a visible light photocatalyst", Chem. Eng. J., 229: 126-133.

23. Khorsand, Z. A., Wang, H. Z., Yousefi, R., Moradi, G. A., Ren, Z. F., (2013). "Sonochemical synthesis of hierarchical ZnO nanostructures", Ultrason. Sonochem, 20 (1): 395-400.

24. Omri, K., Najeh, I., Dhahri, R., El Ghoul, J., El mir, L., (2014). "Effects of temperature on the optical and electrical properties of ZnO nanoparticles synthesized by sol-gel method", Microelectron. Eng., 128: 53-58.

25. Khorsand, Z. A., Abrishami, M. E., Abd Majidi, W. H., Yosefi, R., Hosseini, S. M., (2011). "Effects of annealing temperature on some structural and optical properties of $\mathrm{ZnO}$ nanoparticles prepared by a modified sol-gel combustion method", Ceram. Inter., 37(1): 393-398.

26. Wang, Y., Zhang, C., Bi, S., Luo, G., (2010). "Preparation of $\mathrm{ZnO}$ nanoparticles using the direct precipitation method in a membrane dispersion micro-structured reactor", Powder Technol., 202(1-3): 130136.

27. Sundrarajan, M., Ambika, S., Bharathi, K., (2015). "Plant-extract mediated synthesis of $\mathrm{ZnO}$ nanoparticles using Pongamia pinnata and their activity against pathogenic bacteria", Adv. Powder Technol., 26: 1294-99.

28. Olad, A., Ghazjahaniyan, F., Nosrati, R., (2018). "A Facile and Green Synthesis Route for the Production of Silver Nanoparticles in Large Scale", Int. J. Nanosci. Nanotechnology. 14(4): 289-296. 29. Geoprincy, G., Vidhya srri, B. N., Poonguzhali, U., Nagendra, N. G., Renganathan, S., (2014). "A review on green synthesis of silver nanoparticles", Asian J. Pharm. Clin. Res., 6(1): 8-12. 
30. Ahmed, S., Ahmad, M., Swami, B. L., Ikram, S., (2016). "A review on plants extract mediated synthesis of silver nanoparticles for antimicrobial applications: a green expertise", J. Adv Res., 7(1): 17-28.

31.Soltanabad, M. H., Bagherieh-Najjar, $M$. B., Baghkheirati, E. K., Mianabadi, M., (2018). "Ag-Conjugated Nanoparticle Biosynthesis Mediated by Rosemary Leaf Extracts Correlates with Plant Antioxidant Activity and Protein Content", Int. J. Nanosci. Nanotechnol., 14(4): 319-325

32. Ghanbari, M., Bazarganipour, M., Salavati-Niasari, M., (2017). "Photodegradation and removal of organic dyes using cui nanostructures, green synthesis and characterization", Separation and Purification Technology, 173: 27-36

33. Divya, M. J., Sowmia, C., Joona, K., Dhanya, K. P., (2013). "Synthesis of zinc oxide nanoparticles from Hibiscus rosasinensis leaf extract and investigation of its antimicrobial activity", Res. J. Pharm. Biol. Chem., 4(2): $1137-1142$.

34. Dobrucka, R., Dugaszewska, J., (2015). "Biosynthesis and antibacterial activity of ZnO nanoparticles using Trifolium pratense flower extract", Saudi J. of Biological Sci., 23(4): 517-523.

35. Shah, R. K., Boruah, F., Parween, N., (2015). "Synthesis and Characterization of ZnO Nanoparticles using Leaf Extract of Camellia sinesis and Evaluation of their Antimicrobial Efficacy", Int. J. Curr. Microbiol. App. Sci., 4(8): 444-450

36. Sundaramurthy, N., Parthiban, C., (2015). "Biosynthesis of copper oxide nanoparticles using Pyrus pyrifolia leaf extract and evolve the catalytic activity",
Int. Res. J. of Eng. and Technol. (IRJET), 2(6), 332-338.

37. Reddy, L. S., Nisha, M. M., Joice, M., Shilpa, P. N., (2014). "Antibacterial activity of zinc oxide ( $\mathrm{ZnO}$ ) nanoparticle against Klebsiella pneumonia", Pharmaceutical biology, 52(11): 1388-1397.

38. Fasihuddin, B. A., Sallehuddin, N.K.N.M., \& Assim, Z. (2010). Chemical constituents and antiviral study of Goniothalamus velutinus. Malaysian Journal of Fundamental and Applied Sciences, 6(1), 73-76.

39. Umaru, I. J., Umaru H. A., \& Umaru K. I. (2020). Zinc Oxide Nanoparticles Biosynthesis using Leptadenia hastata Leaf Extracts and their Potential as Antimicrobial Agents. International Journal of Innovative Science and Research Technology, 5(4), 94-100.

40. Yang, K., Lin, D., Xing, B., (2009). "Interactions of humic acid with nanosized inorganic oxides", Langmuir, 25(6): 3571-3576.

41. Umaru, I. J., Fasihuddin, A. B., Zaini, B. A, Umaru, H. A., (2018b). "Antibacterial and cytotoxic actions of chloroform crude extract of Leptadenia hastata(pers)Decnee", Clinical Medical Biochem., 4: 1-4

42. Umaru, I. J., Fasihuddin, B. A., Otitoju, $O$. O., Hauwa, A. U., (2018). "Phytochemical Evaluation and Antioxidant Properties of Three Medicinal Plants Extracts", Med. \& Anal. Chem. Int. J. Phytochem. Eval., 2(2): $1-8$.

43. Zheng, Y., Fu, L., Han, F., Wang, A., Cai, W., Yu, J., Yang, J., Peng, F., (2015). "Green biosynthesis and characterization of zinc oxide nanoparticles using Corymbia citriodora leaf extract and their 
photocatalytic activity", Green Chem. Lett. and Revs., 8(2): 59-63

44. Mohammadi-Aloucheh, R., HabibiYangjeh, A., Bayrami, A., Latifi-Navid, S., Asadi, A., (2018). "Enhanced antibacterial activities of $\mathrm{ZnO}$ nanoparticles and $\mathrm{ZnO} / \mathrm{CuO}$ nanocomposites synthesized using Vaccinium arctostaphylos L. fruit extract", Artificial Cells, Nanomedicine, and Biotechnology, 46(1): 1200-1209.

45. Geetha, A., Sakthivel, R., Mallika, J., Kannusamy, R., Rajendran, R., "Green synthesis of antibacterial zinc oxide nanoparticles using biopolymer Azadirachta indica Gum", Orient. J. Chem., 2016; 32: 955-963.

46. Daphedar, A., Taranath, T. C., (2018). "Green synthesis of zinc nanoparticles using leaf extract of Albizia saman (Jaca.) Merr. And their effect on root meristems of Drimia indica (Roxb.) Jessop", Caryologia., 71: 93-102.

47. Khatami, M., Alijani, H. Q., Heli, H., Sharifi, I., (2018). "Rectangular shaped zinc oxide nanoparticles: Green synthesis by Stevia and its biomedical efficiency", Ceram. Int., 44: 15596-602.

48. Shankar S, Rhim J W., (2017). "Facile approach for large-scale production of metal and metal oxide nanoparticles and preparation of antibacterial cotton pads", Carbohydr Polym., 163: 137-145.

49. Nagarajan, S., Arumugam, K. K., (2013). "Extracellular synthesis of zinc oxide nanoparticle using seaweeds of Gulf of Mannar", India. J. Nanobiotechnol., 11: 39.

50.Shadrokh, Z., Yazdani, A., Eshghi, H., (2017). "Study on Structural and Optical Properties of Wurtzite Cu2ZnSnS4 Nanocrystals Synthesized via Solvothermal
Method", Int. J. Nanosci. Nanotechnology. 13(4): 359-366.

51. Divyapriya, S., Sowmia, C., Sasikala, S., (2014). "Synthesis of zinc oxide nanoparticles and antimicrobial activity of Murraya koenigi", World J. Pharm Sci., 3(12): 1635-1645. 